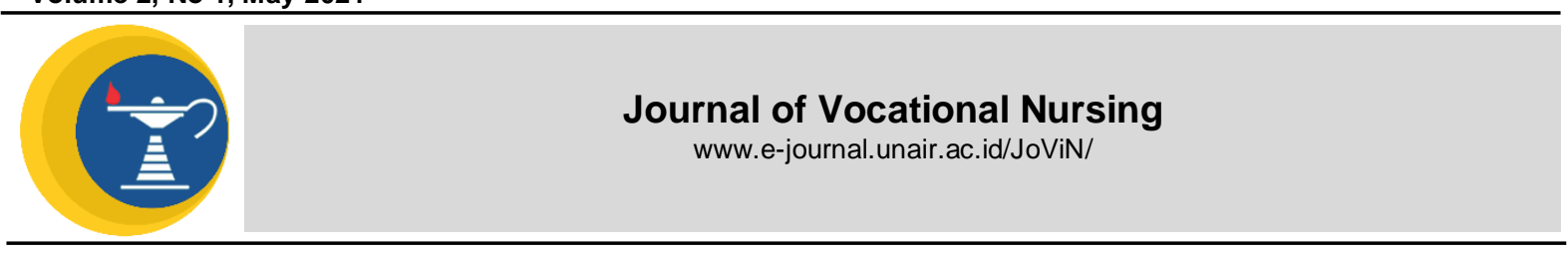

\title{
NURSING CARE FOR ACUTE PAIN RELATED TO GASTRITIS AT ANGGREK ROOM RSI NASHRUL UMMAH LAMONGAN
}

Rohmat Al Baihaqi

RS Semen Gresik
Research Report

ARTICLE INFO

\section{A B STRACT}

Introduction: Gastritis is a problem that many people experience and can occur at various ages. The most common symptom for gastritis sufferers is acute pain. However, acute pain nursing care in gastritis patients is different. This study is to explain Acute Pain Nursing Care for Gastritis Clients at Anggrek Room RSI Nashrul Ummah Lamongan. Methods: This study used case study design. Sampling of this study was one child suffering from gastritis with acute pain symptom. Data of this study were collected by interview, observation, physical examination and documentation. The data that obtained were analyzed with descriptive methods, diagnosis and evaluation. Results: The results showed that there were several gaps between case and theories for the assessment stage. A gap occurs in the assessment of the physical examination of the nasal passages which reveals the presence of nasal lobe breathing while holding pain. The priority of nursing diagnosis was acute pain and the focus of interventions was on pain management. Conclusion: Providing implementation of non-pharmacological techniques (distraction and relaxation techniques) and pharmacological (collaboration providing analgesics), environmental management, touch management, providing knowledge of the causes of pain and efforts to reduce pain, and observation of conditions that are effective in reducing pain in patients.

\author{
Recived 18 May 2021 \\ Accepted 26 May 2021 \\ Online 31 May 2021 \\ ${ }^{*}$ Correspondence: \\ Rohmat Al Baihaqi \\ *Email: \\ Rohmatbaihaqi55@gmail.com
}

Keywords:

Gastritis, acute pain, Nursing care

\section{INTRODUCTION}

Gastritis is a health disorder that is most often encountered, because the diagnosis of gastritis is often only based on clinical symptoms, not a histopathological examination. Gastritis is an inflammation of the gastric mucosa caused by the $\mathrm{H}$. pylori which is acute, chronic, diffuse or local (Hirlan, 2009). Gastritis can occur suddenly (acute gastritis) or gradually (chronic gastritis). Most cases of gastritis do not permanently damage the stomach but someone who has gastritis often has recurrences that cause heartburn (Ehrlich, 2011).

According to the World Health Organization (2012), gastritis in the world about 1.8-2.1 million of the total population each year. The incidence rate in Southeast Asia is around 583,635 of the total population each year. According to $\mathrm{WHO}$, the incidence of gastritis in Indonesia is $40.8 \%$, and the incidence of gastritis in several regions in Indonesia is quite high with a prevalence of 274,396 cases out of $238,452,952$ people (Kurnia, 2011). Based on
Indonesia's health profile in 2011, gastritis is one of the top 10 diseases in hospitalized patients in Indonesia with a total of 30,154 cases (4.9\%) (Depkes, 2012). Data obtained from the Medical records of RSI Nashrul Ummah Lamongan patients with gastritis in 2016 were 353 of 8,432 patients $(4.18 \%)$, in 2017 there were 673 of 7525 patients $(8.94 \%)$, and in January to May 2018 there were 215 of 2733 patients $(7.86 \%)$, the number of gastritis patients in children in the Anggrek room for 3 consecutive years 2016, amounted to 8 of 783 patients (1.02\%), 2017 amounted to 9 of 788 patients $(1.14 \%)$, January to March year 2018 amounted to 3 out of 214 patients (1.4\%), from these data cases of gastritis had increased $(0.12 \%)$.

Symptoms that are common in sufferers gastritis is discomfort (pain) in the epigastrium that can interfere with daily activities (Nurhayati \& Cahyati, 2016). The inflamed mucosa in patients with gastritis often causes pain, causes a diffuse burning pain that is transferred to the upper epigastrium, and 
usually the patient also feels nausea and vomiting, and if it gets worse can cause bleeding, pain usually occurs in the upper left abdomen so that the patient often cries and holds his stomach (Guyton \& Hall, 2012).

Pain is a condition that causes a feeling of suffering and unpleasantness. Gastritis patients need to be addressed immediately so as not to cause more serious problems and can worsen the patient's condition. Therefore, the researcher conducted a case study of acute pain nursing care in gastritis patients at Anggrek room RSI Nashrul Ummah Lamongan.

\section{MATERIALS AND METHODS}

This study used case study design. The sampling of this study was one child suffering from gastritis with acute pain symptom at Angrek room RSI Nashrul Ummah Lamongan. This study was conducted on April 26 - May 11 2018 through a nursing process approach

Data of this study were collected by interview, observation, physical examination and documentation. The data that obtained were analyzed with descriptive methods, diagnosis and evaluation. before being analyzed, the data validity test was conducted.

\section{RESULTS AND DISCUSSION Assessment}

The assessment of the patient's identity shows conformity with the theory that the patient is male. According to Muttaqin \& Sari (2013) Gastritis can occur in men, women, and children of all ages, but men are at risk of developing gastritis than women. Interviews with the patient's mother found that the complaints that children often experience are pain in the upper left abdomen and feeling nauseous. This is in accordance with the theory that the most common complaint in gastritis patients is pain, especially in the gut, people who usually suffer from this disease usually have symptoms of nausea, vomiting, feeling full, and discomfort (Misnadiarly, 2009).

The patient's resting pattern has difficulty sleeping at night, the patient often wakes up and cannot even sleep due to pain, and rarely takes a nap. According to Muttaqin \& Sari (2013) daily activity patterns and sleep rest patterns in gastritis patients experiencing sleep disturbances. There is no gap between the case review and the theoretical review because inflammation of the gastric mucosa can cause so much pain that sleep rest is disturbed.

Examination of the client's nose found normal breathing and no nostril breathing. Muttaqin \& Sari (2013) said that on examination of the nose of a client with gastritis, there will be rapid breathing and exhalation of the nostrils due to the patient's compensation mechanism in holding pain. There is a gap between the case review and the theoretical review because when the client is in the hospital the nasal cannula type oxygen is attached so that breathing is normal and there is no nasal lobe breathing.

\section{Nursing diagnosis}

There is agreement between the theory and the case in which the nursing diagnosis in the patient is acute pain associated with a physiologic injury agent (inflammation of the gastric mucosa). This acute pain can lose control of the body so that it can result in disruption of activities (SDKI, 2017).

Acute pain is a nursing problem that must be addressed immediately, because if it continues it will cause feelings of torment and discomfort. So the authors take the acute pain nursing diagnosis as a top priority because it refers to the client's condition.

\section{Nursing Interventions}

The interventions between literature review and case review in the diagnosis of acute pain associated with physiologic injury agents (gastric mucosal inflammation) are gaps. Vital signs observation interventions every 8 hours were carried out in the case review but in the theoretical review according to Muttaqin \& Sari (2013) there was no. This action is carried out to determine the general condition of the client and changes in vital signs, especially pulse temperature, is an indication of the increased pain experienced by the client.

Nursing interventions aim to solve problems with clients within a specified time. Case study nursing diagnosis of acute pain associated with physiologic injury agent (inflammation of the gastric mucosa) with outcome criteria: the client is relaxed, not restless, and can sleep soundly; Less pain (Scale 0-2); Moist lip mucosa; Can identify activities that increase or decrease pain; vital signs within normal limits (SLKI, 2017). Meanwhile, from the nursing plan, namely: 1 ) Explain and help clients with nonpharmacological and non-invasive pain relief measures. 2) Rest the client when the pain appears. 3) Teach deep breath relaxation techniques when pain occurs. 4) Teach distraction techniques in times of pain. 5) Observation of TTV every 8 hours. 6) Environmental management: quiet environment, limit visitors, and rest clients. 7) Perform touch management. 8) Increase the client's knowledge of the causes of pain and relate how long the pain will last. 9) 
Collaboration in providing analgesic drugs (SIKI, 2017).

\section{Nursing Implementation}

The implementation of nursing actions is carried out in accordance with the plans that have been made. All actions performed on clients are documented in nursing records. Implementation of nursing on the first day 9 items according to the interventions that have been compiled. The first day of nursing implementation, there is no gap between literature review and case review. This is evidenced by the implementation carried out in accordance with the gravity of the problem, the most life-threatening problem in this case is pain so it gets a high priority.

On the second day, 9 items were still carried out because the patient's condition had not changed the results criteria to be achieved. On the third day, 7 items were carried out, which were not done, namely increasing the knowledge of the client's mother about the causes of pain and providing an explanation to the client's mother about non-pharmacological and non-invasive pain relief measures because on the third day the problem had been resolved, so the next step was to adjust the development of the client. On the fourth day, 6 items were carried out, and on the fifth day, 4 items were carried out plus a Discharge Planning. Implementation refers to the implementation of the nursing plan that has been prepared.

\section{Nursing Evaluation}

Nursing evaluation is carried out through periodic monitoring of the patient's condition to assess the effectiveness of nursing implementation given. Although the evaluation stage is placed at the end of the nursing process, evaluation is an integral part of every stage of the nursing process (Yulianingsih, 2015). After conducting an assessment of the nursing care that has been given to the client, the final results obtained are in accordance with the time specified in the planning with the time to achieve the goals of the same planning. This is evidenced by the fifth day with the results: the client's face is relaxed, the client does not look restless, and can sleep soundly, the pain scale is 1 , and TTV is within normal limits. This success may be due to good cooperation between researchers, clients, and the medical team who are both nurses and doctors in the room.

\section{CONCLUSION}

Providing implementation of nonpharmacological techniques (distraction and relaxation techniques) and pharmacological (collaboration providing analgesics), environmental management, touch management, providing knowledge of the causes of pain and efforts to reduce pain, and observation of conditions that are effective in reducing pain in patients.

\section{REFERENCES}

Ehrlich. (2011). Gastritis. Retrieved from http://www.umm.edu/altmed/articles/gast ritis- 000067.htm\#ixzz1xjJUAWU2.

Guyton, A. C., \& Hall, J. E. (2012). Buku Ajar Fisiologi Kedokteran Edisi 11. Jakarta: EGC.

Herdman, T. Heather. (2012). Nursing Diagnosis Definition and Classification 2012 - 2014. Jakarta: EGC.

Hirlan. (2009). Gastritis dalam IImu Penyakit Dalam.

Kurnia. (2011). Faktor - Faktor Yang Berhubungan Dengan Kejadian Gastritis Pada Pasien Yang Berobat Jalan Di Puskesmas Gulai Bancah Kota Bukit Tinggi.

Misnadiarly. (2009). Mengenal Penyakit Organ Cerna : Gastritis (Dyspepsia atau Maag). Jakarta: Pustaka Populer OBDA.

Muttaqin, A., \& Sari, K. (2013). Gangguan Gastrointestinal: Aplikasi Asuhan Keperawatan Medikal Bedah. Jakarta: Salemba Medika.

Nurhayati, S., \& Cahyati, W. H. (2016). Hubungan Antara Status Medical Check Up Terhadap Kejadian Disabilitas Fisik Pada Lansia Di Kecamatan Punung Kabupaten Pacitan. Unnes Journal of Public Health, 5(1), 84. https://doi.org/10.15294/ujph.v5i1.9710

SDKI. (2017). Indonesian Nursing Diagnosis Standards. PPNI.

SIKI. (2017). Indonesian Nursing Intervention Standards. PPNI.

SLKI. (2017). Indonesian Nursing Output Standards. PPNI.

Yulianingsih. (2015). Konsep Dasar Keperawatan. Jakarta: Salemba Medika 